\title{
Structural Features of the East Asian Food Systems and Dynamics: Implications from a Case Study of Develop-and-Import Scheme of Umeboshi
}

\author{
NORITO Takashi \\ Graduate School of Agriculture, Kyoto University, Kyoto 606-8502, Japan. \\ E-mail: noritou.takashi.27e@st.kyoto-u.ac.jp
}

Received May 27, 2011; Accepted December 6, 2011

\begin{abstract}
This article defines the East Asian food systems as chains of food production, supply and consumption in East Asia, and analyzes the structural characteristics and dynamics. First, to clarify the concept, this paper presents two analytical viewpoints of the East Asian food systems as a "collective entity" (comprehending each nation's food system separately) and as a "joint entity" (an intersection of each nation's food system through intra-regional food trade), and describes each of the structural characteristics and dynamics with statistical data. As for the "collective entity," its structural characteristics involve Westernization and sophistication of diets in East Asian countries. With regard to the "joint entity," one of its structural characteristics is a trade expansion in processed foods exported from China and ASEAN states and imported to Japan. Second, in order to illuminate the deployment of Japanese agribusinesses that have led the trade growth of processed foods, this article focuses on umeboshi, Japanese plum with a long history of foreign trade, and analyzed the roll-out of the develop-and-import schemes by the umeboshi processors. As the base of the develop-and-import schemes has moved from Taiwan to China in the 1990s, this article has looked at the transfer process in depth, and found that important factors are cultural and political distances that affect business relations between umeboshi processors as micro-level agents, in the midst of such macro-scale movement as economic development in East Asia.
\end{abstract}

Key words East Asian food systems, food trade, develop-and-import scheme, agribusiness, cultural/political distances

\section{Introduction}

An upsurge in grain prices such as wheat and maize between 2007 and 2008, brought food security to a critical political issue for the East Asian region (Suzuki 2008; Toyoda 2009). Since this stringent food supply is expected to loom in the future, it is required for countries in East Asia to cooperate with each other and construct secure food systems: the whole systems from food production, to supply and consumption. ${ }^{1}$ In search for its direction, the existing circumstances and their changes should be first examined.

In this article, the East Asian food systems are defined as chains of food production, supply and consumption in East Asia, and its structural characteristics and dynamics are analyzed. The focus here is food imports to Japan. It goes without saying that the position of Japan in the East Asian food systems is important. Japan imports a large amount of foods, processed foods in particular, from East Asia. Conversely, the East Asian region exports a large amount of foods, mainly processed foods, to Japan. This is a main pattern in the region's food trade. A food trade could be considered a conjunction of each state's food system, and it could be assumed that we can approach the structures of the East Asian food systems by focusing on this main pattern.

This article also highlights some activities of Japanese agribusinesses (food processors, food manufacturers, and trading companies). They have imported a variety of foods from the region, using a method called "developand-import." A develop-and-import method is a trade practice that companies develop products based on their own specifications or standards, and import the products (Ministry of Agriculture, Forestry and Fisheries 1995). Behind the expansion of the intra-regional food trade has been the active deployment of develop-and-import schemes by these agribusinesses.

As a clue to deepen the analysis from this perspective, this article focuses on the case of umeboshi (Japanese pickled plums), a traditional food in Japan. In spite of the tradition, the food system of umeboshi is underpinned by imports of raw materials and products from the East Asian region (Norito 2011). The history of the umeboshi international trade is long, as Japanese umeboshi 
processors have been engaged in the develop-and-import scheme in Taiwan and China for half a century. It can be assumed that the dynamics of the East Asian food systems could be approached by tracing the half-century history of the umeboshi develop-and-import scheme.

Finally, the most unique contribution of this article is to approach the East Asian food systems as a macrolevel object, from the viewpoint of a micro-level agent of agribusinesses. Most previous studies on the East Asian food systems have been preoccupied with a panoramic grasp of the structure, by analyzing the overall data on the entire food trade (Kanada 2008; Shimowatari and Natori 2010). However, through examining the deployment of the develop-and-import scheme of umeboshi processors as a micro-level agent, this article aims to look closely into the reality of the East Asian food systems.

Here below I discuss the related theories and approaches to analysis of the structural characteristics and the dynamics of the East Asian food systems. Firstly, a food system is sometimes explained as a theoretical system (Takahashi and Saito 2002), but there is actually a mosaic of various theories such as the distribution theory and the theory of industrial organization. In previous studies on food system analysis, each author utilized different theories and approaches (see Niiyama 2001; Tsujimura 2004; Takayanagi 2006). Since this article also sets the East Asian food systems as the focal concept, basic theories and specific devices of analysis need to be defined.

This article uses the food regime theory and commodity chains approach as references. Influenced by the world systems theory, the two theories attempt to unravel relationships between advanced and developing countries, as well as disparities in the world economy, from the standpoint of political economy. The food regime theory discusses the international political regimes over food production and consumption, and historical transitions on a world scale. ${ }^{2}$ The commodity chains approach attempts to understand the world economy, especially the relationship between producing and consuming countries, by analyzing the processes of a commodity from production to consumption ${ }^{3}$ (Araki et al. 2007). Specifically, as explained in the next section, this article partially incorporates concepts from the food regime theory and commodity chains approach on the following points. First, the East Asian food systems constitute a part of the global food system. Second, the article looks at activities of agribusinesses as major agents. And third, the article approaches the structural features and the changes of the East Asian food systems, through the medium of one particular commodity, umeboshi.

One model commonly cited in analyzing the dynamics of the East Asian food systems is the flying geese (ganko keitai) model (Kojima 2000; Dowling and Cheang 2000). It likens the development process of the East Asian economy to geese flying in a V-formation with a leader at the forefront. But the theoretical viewpoints between the flying geese model and the two theories of food regime and commodity chains are very different. While the flying geese paradigm is a positive economic model that assumes the smooth progress of developing nations, the food regime theory and commodity chains approach pay attention to some negative aspects such as NorthSouth problems and the disparities of the world economy. In order to explore the direction of sustainable and secured development of the East Asian food systems, it is important to analyze the relationship between Japan ("the center") and the East Asian region ("the periphery") in depth as a background to the economic development of East Asia, including the negative dimensions. Since these negative points are less visible in the flying geese model, this article takes the theoretical standpoint of the food regime theory and commodity chains approach.

Furthermore, this article employs concepts of "cultural distance" and "political distance" as specific devices of analysis, in order to depict a logic of expansion in the develop-and-import schemes by the umeboshi processors. The two concepts are used in geography (Gertler 1993; Mizuno 1997, 2001) and international business studies (Pankaj 2007). The concept of cultural distance signifies commonalities of cultural backgrounds including language, religions, values and norms as well as the extent of trust (Pankaj 2007). Also, political distance includes the degree of difference in political stances, bias toward domestic industries and companies, and openness of market, etc. (Pankaj 2007) These two distances remain important for companies in expanding businesses domestically and internationally-even in a borderless modern society (Pankaj 2007). Exploiting these concepts enables us to explain some behavioral logic of corporations operating across borders, not only from the economic dimension, but also from the social dimension.

To come right to the point, in the case of umeboshi, since the 1990s it has not been Japanese umeboshi processors and traders, but Taiwanese processors that have played a leading role in moving the base of the develop-and-import schemes from Taiwan to Southern China. This article examines the reasons in terms of cultural and political distances among Japanese, Taiwanese and Chinese processors. 


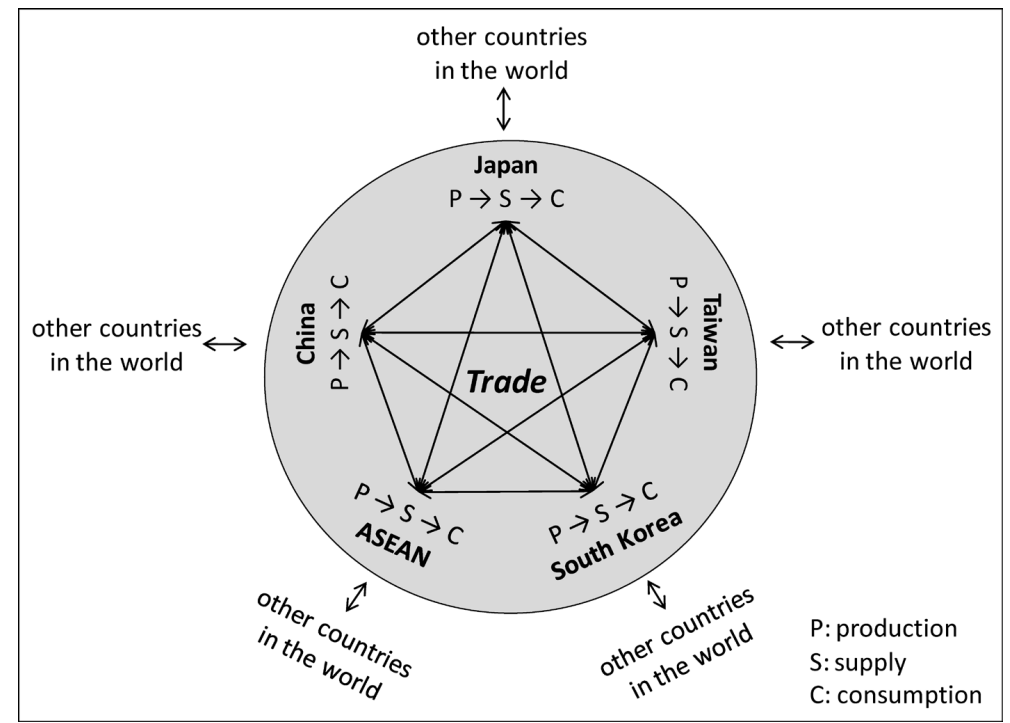

Figure 1. Concept of the East Asian food systems.

In this article, analyses are undertaken in the following order. In the next section, the concept of the East Asian food systems is examined. Also, the structural features of the East Asian food systems are described with statistics and findings from preceding works. Section Three explains some inherent attributes of umeboshi and outlines its trade trend from statistical data. Expansion processes of develop-and-import schemes by umeboshi processors are analyzed in the fourth section, based on three periods of time. Section Five develops the analysis of the dynamics of the East Asian food systems through a case study of umeboshi develop-and-import schemes.

The followings are three sources of data used in this article. First is some quantitative data on intra-regional food trade to demonstrate the structural features of the East Asian food systems. "FAOSTAT" by the Food and Agriculture Organization (FAO) and The United Nations' "UN Comtrade" are useful in this regard. Second is further quantitative data on umeboshi trade obtained from Trade Statistics of Japan, available from Japan's Ministry of Finance. Third is some qualitative data concerning the develop-and-import schemes by umeboshi processors. For this, the author conducted interviews with management executives and staff in charge of trade from three companies closely associated with the developand-import schemes, selected from umeboshi processors located in Minabe and Tanabe areas, Wakayama prefecture, which are known for Japan's largest areas of processing umeboshi. The interviews were undertaken in April and October, 2010.

\section{Concept of the East Asian Food Systems}

\section{Reviews of the concept}

The concept of the East Asian food systems is examined here. First, this article refers to East Asia as Japan, China, Taiwan, South Korea and the nations belonging to the Association of Southeast Asian Nations (ASEAN). The state of each nation's food system differs depending on the speed and stages of economic development. Keeping such differences in mind, this article presents an analytical viewpoint that defines the East Asian food systems as a "collective entity" as well as a "joint entity" of each country's food system (Figure 1). As a "collective entity," the structures can be approached by analyzing first the state of each nation's food system (production, supply, and consumption) individually, and next commonalities and differences of each nation's food system. As a “joint entity," in contrast, it can be considered that each nation's food system is combined through the food trade, and its structures are approachable by looking into the main patterns of the intra-regional food trade and the trade structures. Although it is true that both approaches are needed to unveil the whole picture of the East Asian food systems, this article is based on the latter approach by analyzing the food trade in one particular commodity.

Two points are worth consideration in the above conceptualization. First is its dynamics. The post-war East Asian economy has been growing dramatically. Needless to say, it is Japan that has led the economic development of East Asia. Japan achieved high economic growth in the 1960s, and developed as the sole advanced nation in Asia. In the 1980s, in contrast with Japan entering the period of low growth, the economies of Hong Kong, Taiwan, South 
Table 1. Top agricultural commodities imported by Japan, China and Thailand

\begin{tabular}{|c|c|c|c|c|c|c|}
\hline \multirow{2}{*}{ Country } & \multirow{2}{*}{ Year } & \multicolumn{5}{|c|}{ Commodities Imported } \\
\hline & & $1 \mathrm{st}$ & 2nd & $3 r d$ & 4 th & 5 th \\
\hline \multirow[t]{2}{*}{ Japan } & 1988 & $\begin{array}{l}\text { Maize } \\
2,095,090\end{array}$ & $\begin{array}{l}\text { Pork } \\
1,655,830\end{array}$ & $\begin{array}{l}\text { Soybeans } \\
1,428,830\end{array}$ & $\begin{array}{l}\text { Beef } \\
1,098,300\end{array}$ & $\begin{array}{l}\text { Wheat } \\
\qquad 1,033,900\end{array}$ \\
\hline & 2008 & $\begin{array}{l}\text { Maize } \\
5,602,460 \\
\end{array}$ & $\begin{array}{l}\text { Pork } \\
4,170,850 \\
\end{array}$ & $\begin{array}{l}\text { Wheat } \\
3,291,570\end{array}$ & $\begin{array}{l}\text { Soybeans } \\
2,374,210\end{array}$ & $\begin{array}{l}\text { Beef } \\
2,144,970\end{array}$ \\
\hline \multirow[b]{2}{*}{ South Korea } & 1968 & $\begin{array}{l}\text { Wheat } \\
62,788\end{array}$ & $\begin{array}{l}\text { Rice } \\
43,304\end{array}$ & $\begin{array}{l}\text { Barley } \\
11,806\end{array}$ & $\begin{array}{l}\text { Sugar } \\
\qquad 10,169\end{array}$ & $\begin{array}{r}\text { Flour of Wheat } \\
5,337\end{array}$ \\
\hline & 1988 & $\begin{array}{l}\text { Maize } \\
579,615\end{array}$ & $\begin{array}{l}\text { Wheat } \\
542,455\end{array}$ & $\begin{array}{l}\text { Soybeans } \\
292,639\end{array}$ & $\begin{array}{l}\text { Sugar } \\
\qquad 262,547\end{array}$ & $\begin{array}{r}\text { Cake of Soybeans } \\
101,094\end{array}$ \\
\hline \multirow{3}{*}{ China } & 1968 & $\begin{array}{l}\text { Wheat } \\
366,210\end{array}$ & $\begin{array}{l}\text { Soybeans } \\
44,315\end{array}$ & $\begin{array}{l}\text { Sugar } \\
30,000\end{array}$ & $\begin{array}{l}\text { Maize } \\
29,606\end{array}$ & $\begin{array}{r}\text { Milk Whole Dried } \\
7,929\end{array}$ \\
\hline & 1988 & $\begin{array}{l}\text { Wheat } \\
1,891,443\end{array}$ & $\begin{array}{l}\text { Sugar } \\
757,601\end{array}$ & $\begin{array}{l}\text { Soybean Oil } \\
589,787\end{array}$ & $\begin{array}{l}\text { Maize } \\
562,265 \\
\end{array}$ & $\begin{array}{l}\text { Palm Oil } \\
191,894 \\
\end{array}$ \\
\hline & 2008 & $\begin{array}{l}\text { Soybeans } \\
22,980,480\end{array}$ & $\begin{array}{l}\text { Palm Oil } \\
5,342,208\end{array}$ & $\begin{array}{r}\text { Soybean Oil } \\
3,367,750\end{array}$ & $\begin{array}{r}\text { Chicken Meat } \\
1,281,074\end{array}$ & $\begin{array}{l}\text { Maize } \\
1,164,811\end{array}$ \\
\hline \multirow{3}{*}{ Thailand } & 1968 & $\begin{array}{l}\text { Evaporated Milk } \\
11,897\end{array}$ & $\begin{array}{r}\text { Milk Whole Dried } \\
3,503\end{array}$ & $\begin{array}{l}\text { Wheat Milk } \\
\text { 3,124 }\end{array}$ & $\begin{array}{r}\text { Skimmed Dry } \\
2,990\end{array}$ & $\begin{array}{l}\text { Coffee } \\
\qquad 2,205\end{array}$ \\
\hline & 1988 & $\begin{array}{r}\text { Skimmed Dry Milk } \\
319,313\end{array}$ & $\begin{array}{r}\text { Cake of Soybeans } \\
59,185\end{array}$ & $\begin{array}{r}\text { Milk Whole Dried } \\
43,624\end{array}$ & $\begin{array}{l}\text { Wheat } \\
39,743\end{array}$ & $\begin{array}{r}\text { Cake of Groundnuts } \\
18,347\end{array}$ \\
\hline & 2008 & $\begin{array}{r}\text { Cake of Soybeans } \\
1,028,060\end{array}$ & $\begin{array}{l}\text { Soybeans } \\
968,695\end{array}$ & $\begin{array}{l}\text { Wheat Milk } \\
\text { 331,629 }\end{array}$ & $\begin{array}{r}\text { Skimmed Dry } \\
228,377\end{array}$ & $\begin{array}{l}\text { Malt } \\
\qquad 150,518\end{array}$ \\
\hline
\end{tabular}

Source: FAOSTAT

Korea and Singapore largely grew by increasing exports of industrial goods, as they came to be called Asian Newly Industrialized Economies (NIEs). ${ }^{4}$ In the 1990s and later, China and ASEAN nations have accomplished significant economic development, whereas Japan has suffered from the bursting of the bubble economy and the consequent recession. It is an important theme to address how the structures of the East Asian food systems have changed in the midst of these dynamics of the Asian economy.

The second point is recognition from a global perspective. It is certain that the East Asian food systems are not closed within the region. As mentioned below, many East Asian nations are net importing countries that import a huge volume of foods, particularly grains. Hence the East Asian food systems should be recognized as a component of the global food system. That aspect is not discussed in depth in this article, but briefly mentioned in the next section.

\section{Structural features of the East Asian food systems}

First, in order to understand the outline of the East Asian food systems as a "collective entity," that is, commonalities and differences between each nation's food system, some common trends are explained with the use of the findings of Shimowatari (2008). With regard to commonalities, Shimowatari (2008) points out Westernization, sophis-tication of diets and expansion of food imports. In recent years, consumers eat less and less rice largely in the urban areas of East Asia, while Westernization and sophistication of diets, such as the spread of eating out as well as increases in animal product and processed food intakes, have been in progress. Whereas agricultural sectors in each nation are shrinking, food industries (food manufacturers, retailers and restaurants) are expanding. Taiwan, South Korea, China and ASEAN states are following the same path taken by Japan, which, according to Shimowatari (2008), can be regarded as the homogenization of the East Asian food systems.

As diets are being westernized and sophisticated, these countries increase their imports; as a result, they have become net importing nations. Here, in order to comprehend the details of food import expansion, it is worth looking at dominant imported items and their changes in value for South Korea, China, Thailand and Japan, by referring to FAOSTAT (Table 1). In the last 
Table 2. Food trade matrix in East Asia

\begin{tabular}{|c|c|c|c|c|c|c|c|}
\hline \multirow{2}{*}{$\begin{array}{l}\text { Exporting } \\
\text { Countries } \\
\text { and Regions }\end{array}$} & \multirow{2}{*}{ Year } & \multicolumn{5}{|c|}{ Importing Countries and Regions } & \multirow{2}{*}{ Total } \\
\hline & & Japan & South Korea & Taiwan & China & ASEAN & \\
\hline Japan & $\begin{array}{l}1965 \\
1985 \\
2005 \\
\end{array}$ & & $\begin{array}{r}1 \\
9 \\
319(56.0 \%) \\
\end{array}$ & $\begin{array}{r}3 \\
26 \\
327(69.6 \%)\end{array}$ & $\begin{array}{r}- \\
1 \\
297(87.3 \%)\end{array}$ & $\begin{array}{r}24 \\
353 \\
372(85.9 \%)\end{array}$ & $\begin{array}{r}28 \\
389 \\
1,315(75.0 \%)\end{array}$ \\
\hline South Korea & $\begin{array}{l}1965 \\
1985 \\
2005 \\
\end{array}$ & $\begin{array}{r}15 \\
28 \\
1,273(70.6 \%) \\
\end{array}$ & & $\begin{array}{r}2 \\
3 \\
90(49.0 \%)\end{array}$ & $\begin{array}{r}- \\
- \\
222(72.5 \%)\end{array}$ & $\begin{array}{r}2 \\
148 \\
182(91.8 \%) \\
\end{array}$ & $\begin{array}{r}19 \\
179 \\
1,767(71.7 \%) \\
\end{array}$ \\
\hline Taiwan & $\begin{array}{l}1965 \\
1985 \\
2005 \\
\end{array}$ & $\begin{array}{r}138 \\
400 \\
1,039(66.9 \%) \\
\end{array}$ & $\begin{array}{r}2 \\
83 \\
76(85.9 \%) \\
\end{array}$ & & $\begin{array}{r}- \\
- \\
65(78.6 \%)\end{array}$ & $\begin{array}{r}18 \\
571 \\
872(99.2 \%) \\
\end{array}$ & $\begin{array}{r}158 \\
1,054 \\
2,052(75.3 \%) \\
\end{array}$ \\
\hline China & $\begin{array}{l}1965 \\
1985 \\
2005 \\
\end{array}$ & $\begin{array}{r}81 \\
362 \\
7,746(69.8 \%) \\
\end{array}$ & $\begin{array}{r}- \\
- \\
2,570(55.4 \%)\end{array}$ & $\begin{array}{r}- \\
- \\
240(57.4 \%)\end{array}$ & & $\begin{array}{r}66 \\
167 \\
1,698(38.3 \%) \\
\end{array}$ & $\begin{array}{r}147 \\
529 \\
12,254(62.8 \%)\end{array}$ \\
\hline ASEAN & $\begin{array}{l}1965 \\
1985 \\
2005\end{array}$ & $\begin{array}{r}87 \\
2,116 \\
5,481(55.5 \%)\end{array}$ & $\begin{array}{r}1 \\
209 \\
942(55.3 \%)\end{array}$ & $\begin{array}{r}3 \\
66 \\
770(60.5 \%)\end{array}$ & $\begin{array}{r}- \\
7 \\
1,376(73.9 \%)\end{array}$ & $\begin{array}{r}200 \\
312 \\
5,663(79.8 \%)\end{array}$ & $\begin{array}{r}291 \\
2,710 \\
14,232(68.1 \%)\end{array}$ \\
\hline TOTAL & $\begin{array}{l}1965 \\
1985 \\
2005\end{array}$ & $\begin{array}{r}321 \\
2,906 \\
15,539(64.5 \%)\end{array}$ & $\begin{array}{r}- \\
218 \\
3,907(56.2 \%)\end{array}$ & $\begin{array}{r}8 \\
92 \\
1,427(61.3 \%)\end{array}$ & $\begin{array}{r}- \\
8 \\
1,960(74.9 \%)\end{array}$ & $\begin{array}{r}310 \\
1,551 \\
8,787(73.2 \%)\end{array}$ & $\begin{array}{r}643 \\
4,861 \\
31,620(67.1 \%)\end{array}$ \\
\hline
\end{tabular}

Notes:

1. All figures are reported by importing countries, except for Taiwan that does not report to the UN.

2. Figures for China do not include Hong Kong and Macao.

3. "-" means that there is no available data.

4. Figures for ASEAN consist of Indonesia, Malaysia, Philippines, Singapore, Thailand and Vietnam.

5. Figures in which ASEAN's imports and exports cross, indicate trade among the above ASEAN countries.

6. Figures in brackets for 2005 show the ratios of processed foods to all foods.

Date Source: UN Comtrade.

40 years, even taking into account fluctuations of living standards and exchange, food imports have largely grown in all of these countries, particularly in the last 20 years, when globalization has greatly advanced. The changes in items are also noteworthy. For Japan, chief imports have switched from grains to meats in the last 20 years. For China and Thailand, soy beans used as source of oils and feeds for livestock have become key import items. With its vast land, China was once a major exporter of soy beans, but has currently shifted to the world's biggest importer of soy beans. Behind both lie growths in demand of animal products, commonly brought about by westernization and sophistication of diets.

It is important to notice here that meats and soy beans are dependent on imports from outside the East Asia region, such as the United States, Canada and Australia. This signifies that East Asia is positioned as a prime importing or consuming region in the world food system.

Next, it is essential to figure out a general overview of the East Asian food systems as a "joint entity," that is, the intersection of each country's food system through food trade. That can be seen in with the structures of the intraregional food trade, as illustrated in the intra-regional food trade matrix (Table 2), that has been created from the United Nations' "Comtrade" database.

The growing amount of food trade in the East Asia is firstly remarkable: the growth is significant, even taking into consideration the fluctuations in commodity prices and exchange rates. The reasons include not only the expansion in trade volume, but value addition of products due to growth in processed foods. Of the total imports in 2005, processed foods accounted for $64.5 \%$ for Japan, 56.2\% for South Korea, 61.3\% for Taiwan, 74.9\% for China, and $73.2 \%$ for ASEAN countries, indicating that processed foods are the key to the food trade in East Asia. ${ }^{5}$ Also for exports, processed foods have an overall high proportion of $75.0 \%$ for Japan, $71.7 \%$ for South Korea, $75.3 \%$ for Taiwan, $62.8 \%$ for China, and $68.1 \%$ for ASEAN states, that reveals a prosperous horizontal trade of processed foods within the East Asian region.

It is Japan that plays a central role in food imports in the intra-regional trade, and accounts for $49.1 \%$ of all food imports in the region. On the other hand, China and ASEAN nations are the heart of food exports: as of 2005 , the share of China in food exports is $38.7 \%$, and of ASEAN countries $45.0 \%$, thus both account for $83.7 \%$ of the total exports. Accordingly, it can be summarized that the chief pattern of food trade in East Asia is composed 
Table 3. Top food commodities imported from China and Thailand to Japan

\begin{tabular}{|c|c|c|c|c|c|c|c|}
\hline \multirow{2}{*}{ Country } & \multirow{2}{*}{ Year } & \multicolumn{5}{|c|}{ Commodities imported } & \multirow{2}{*}{ Total } \\
\hline & & $1 \mathrm{st}$ & 2nd & $3 r d$ & 4 th & 5 th & \\
\hline \multirow{2}{*}{$\begin{array}{l}\text { South } \\
\text { Korea }\end{array}$} & 1988 & $\begin{array}{l}\text { Tuna (fr) } \\
20,140\end{array}$ & $\begin{array}{l}\text { Arch Shell } \\
\qquad \begin{array}{c}(\mathrm{co}, \mathrm{fr}) \\
11,971\end{array}\end{array}$ & $\begin{array}{r}\text { Tuna (Kihada) (fr) } \\
11,017\end{array}$ & $\begin{array}{r}\text { Octopus etc. (co) } \\
10,801\end{array}$ & $\begin{array}{l}\text { Chestnuts } \\
10,040\end{array}$ & 249,308 \\
\hline & 2008 & $\begin{array}{l}\text { Tuna (fr) } \\
13,049\end{array}$ & $\begin{array}{l}\text { Alcohol } \\
10,056\end{array}$ & $\begin{array}{r}\text { Pickles } \\
7,733\end{array}$ & $\begin{array}{r}\text { Tuna (Mebachi) (fr) } \\
7,230\end{array}$ & $\begin{array}{r}\text { Puffer Fish (fugu) etc. } \\
6,532\end{array}$ & 149,523 \\
\hline \multirow{2}{*}{ Thailand } & 1988 & $\begin{array}{r}\text { Shrimp \& Prawn (fr) } \\
44,055\end{array}$ & $\begin{array}{r}\text { Scrap Chicken } \\
20,570\end{array}$ & $\begin{array}{l}\text { Sugar } \\
15,064\end{array}$ & $\begin{array}{l}\text { Squid (fr) } \\
\qquad 8,530\end{array}$ & $\begin{array}{l}\text { Squid (co) } \\
6,368\end{array}$ & 156,944 \\
\hline & 2008 & $\begin{array}{l}\text { pp of Chicken } \\
85,524\end{array}$ & $\begin{array}{l}\text { Sugar } \\
28,490\end{array}$ & $\begin{array}{l}\text { Pet Foods } \\
23,135\end{array}$ & $\begin{array}{r}\text { Shrimp \& Prawn (fr) } \\
20,621\end{array}$ & $\begin{array}{l}\text { pp of Squid } \\
\qquad 14,088\end{array}$ & 354,489 \\
\hline \multirow{2}{*}{ China } & 1988 & $\begin{array}{r}\text { Shrimp \& Prawn (fr) } \\
47,180\end{array}$ & $\begin{array}{l}\text { Maize } \\
21,104\end{array}$ & $\begin{array}{r}\text { Cake of Soybeans } \\
14,807\end{array}$ & $\begin{array}{l}\text { Soybeans } \\
13,081\end{array}$ & $\begin{array}{r}\text { pp of Vegetables } \\
11,522\end{array}$ & 281,111 \\
\hline & 2008 & $\begin{array}{l}\text { pp of Chicken } \\
52,134\end{array}$ & $\begin{array}{r}\text { pp of Codfish } \\
28,041\end{array}$ & $\begin{array}{l}\text { pp of Crab } \\
20,110\end{array}$ & $\begin{array}{l}\text { pp of Eel } \\
16,677\end{array}$ & $\begin{array}{l}\text { pp of Squid } \\
15,196\end{array}$ & 780,217 \\
\hline
\end{tabular}

pp: processed product, fr: frozen, co: cold storage

Note: The total amounts partly include non-food such as Tabacco.

Source: Trade Statistics of Japan by Ministry of Finance.

of Japan as an importer, and China and ASEAN nations as exporters.

What does Japan, the center of food imports, import from South Korea, China and Thailand? Table 3 indicates large imports of sea-foods such as shrimp/prawn and octopus. Notable here is the change in forms of items. In 1988, shrimp and squid were imported just in chilled or frozen. However at present, most fishery imports are processed. For example, codfish are imported coated with bread crumbs for fried food; and squid cut into pieces and boiled. Likewise the transition from raw materials to processed foods is also understood well from cases of chicken and pet food imported from Thailand. In 1988, Japan imported a large volume of scrap chicken from Thailand (Table 3). It can be assumed that at that time, Japanese food manufacturers imported chicken as scraps and produced chicken nuggets, meatballs or pet food. On the other hand, they currently import processed chicken products and pet food that are manufactured in Thailand. This transition from raw materials to processed foods can be recognized as increasing value-added of the food trade (McMichael 2000).

The expanding trade of processed foods is largely concerned with the development of Japanese agribusinesses. Amid the trend of a strong yen following the Plaza Accord, Japan's agribusinesses became dependent on cheap imported processed foods, because of a growing demand in prepared ingredients brought by "externalization of cooking" (eating out and buying prepared meals) and low-price-oriented needs after the collapse of the bubble economy. It was the develop-and- import schemes that were adopted by agribusinesses then. Therefore, analysis from the next section focuses on deployments of the develop-and-import schemes that have been taken in the East Asia by umeboshi processors, in order to look at the actual conditions of the East Asian food systems.

\section{Umeboshi: Features and Trends in International Trade}

\section{Specifications}

Ume, or Japanese plum, is a raw material of umeboshi, and a plant widely distributed in East Asia that has been cultivated in various locations for eating and for ornamental purposes. Ume is not eaten raw, but consumed after being processed such as dried and its juice extracted, although forms of processing, i.e., ways of eating are different in each country. In China and Taiwan, it is consumed as sweetly pickled plums and oriental medicine, and mainly consumed as plum liquor in Korea. As the largest consumer of ume, Japan has various forms of eating ume, but umeboshi or pickled plums are the most popular and have a long history.

An umeboshi is a salted, dried and seasoned Japanese plum, and one of the most representative of Japanese traditional foods. At present, approximately $60 \%$ of umeboshi supplied is made from Chinese raw material or a final product manufactured in China: thus the umebosh food system would not be viable without China (Norito 2011). This China-dependent structure in the production and processing sectors has been formed in the last 20 


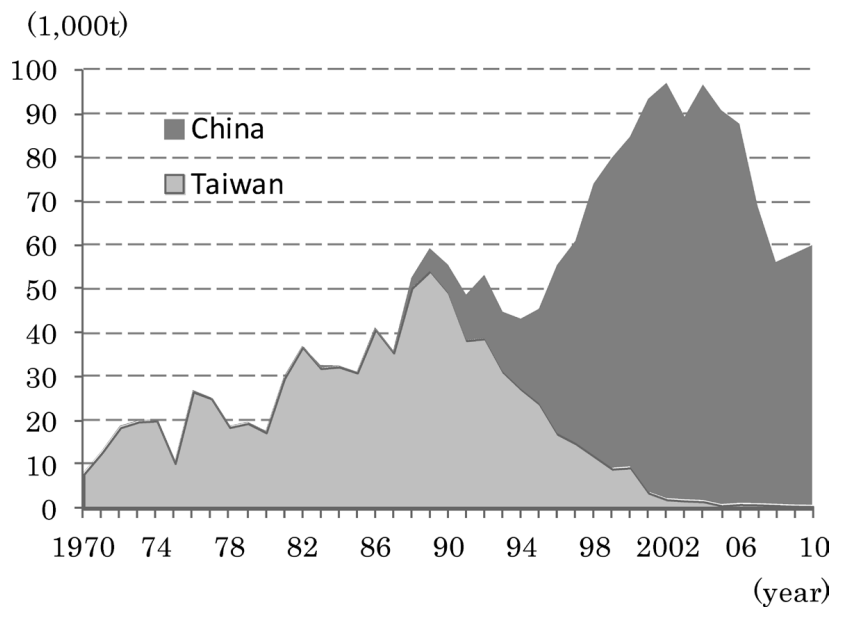

Figure 2. Trends in the import volume of umeboshi to Japan.

Notes:

1. Although there are imports other than from China and Taiwan, these amounts are negligible.

2 All volumes are adjusted to those of green fruits (by doubling the imported volumes).

Source: Trade Statistics of Japan by Ministry of Finance.

years, underpinned by the rise and fall of umeboshi demands in Japan (more fully discussed in next section) as well as by deployment of the develop-and-import schemes propelled by umeboshi processors in response to the changes.

\section{Trends in international trade}

There are some trends of umeboshi imports to Japan which are apparent from Trade Statistics of Japan published by the Japanese Ministry of Finance. Figure 2 shows the transition of umeboshi imports in quantity by origin. The volume of imports was largely expanded from the late 1980 s to the early 2000s. What lies behind this is the growth in demand for umeboshi in Japan. The demand for umeboshi greatly grew between the late 1980s and 1990s, due to the rise of health-conscious consumption and development of "home-meal replacement" industry, i.e., prepared foods ("naka-shoku") and restaurant industries. Since the late 1990s in particular, imports of umeboshi produced in China have burgeoned for low-end consumers and industrial uses, along with the accelaration of yen appreciation and the deflationary economy.

Meanwhile, source of origin for umeboshi has shifted from Taiwan to China. The first import of umeboshi was conducted from Taiwan in 1962, and almost all imported umeboshi to Japan came from Taiwan until the 1990s. However, many Taiwanese processors relocated their manufacturing bases to Fujian and Guangdong Provinces in China in search of cheap and abundant raw materials and labor, following elevated labor costs and a shrinking agricultural sector in Taiwan. The import to Japan reached its peak in volume approximately at $100,000 \mathrm{t}$ in 2002, when more than $70 \%$ of umeboshi consumed in Japan was produced in China.

Nevertheless in the 2000s, demands for green ume and umeboshi have decreased with the maturation of the health-food market and a downturn in the gift market. Imports from China plunged, especially because of mandatory labeling of origin following the amendment of Japanese Association of Surveyors (JAS) laws in October, 2001, together with a series of incidents concerning safety of Chinese food products. ${ }^{6}$

For the following discussion, this article divides the sequence of the umeboshi develop-and-import into three periods: between 1962 and the 1980s as a "Taiwandominant period," from the 1990 s to the early 2000 s as a "period of China-shift and growth," and the late 2000s as a "period of diminished imports."

\section{Develop-and-Import Schemes of Umeboshi Unfurled}

\section{The Taiwan-dominant period (1962-1980s)}

The umeboshi import to Japan was firstly conducted from Taiwan in 1962. Ume (plum), chief material of umeboshi, has a market price sensitive to the harvest condition, that has caused the greatest concern for its procurement among umeboshi processors. Meanwhile, it was around 1960 when one umeboshi sales company (which later became a processing company) located in Wakayama prefecture, obtained information through a Taiwanese merchant, that ume was also cultivated in Taiwan on a large scale. Then a person related to the company researched ume in Taiwan, and he found that it was widely cultivated from the central to the southern parts of Taiwan (Figure 3). Taiwanese do not have a culture of eating umeboshi, but they have a tradition to eat plums as sweets (hua mei and mi jian), whose intermediate materials are almost the same as shiraboshi, the intermediate material of umeboshi. Shiraboshi is salted and dried ume, and it was first imported from Taiwan to Japan in 1962, after Japanese firms negotiated with processing companies there. Since then, imports of shiraboshi were started by Japanese processing and trading companies one after another, and there was also a flood of new entries into processing shiraboshi in Taiwan. Behind the expansion of the shiraboshi import lay the develop-and-import schemes, whose central agent was the umeboshi processors.

The objectives of the develop-and-import scheme 


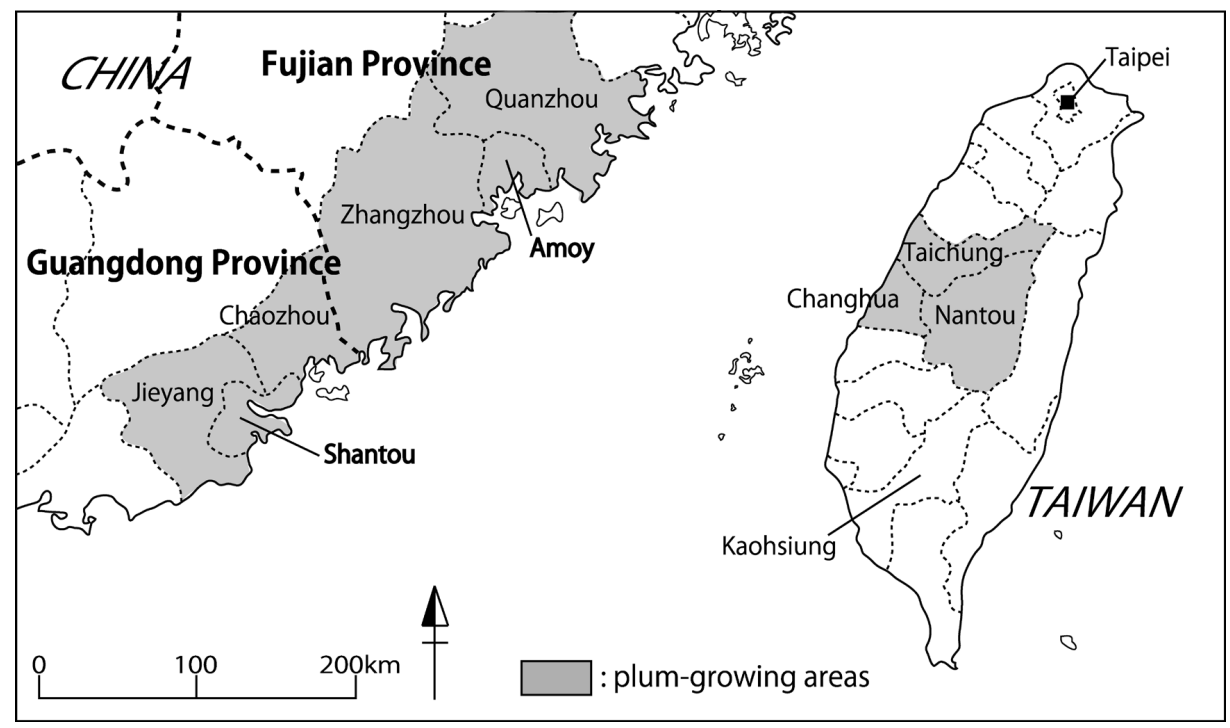

Figure 3. Plum-growing areas in China and Taiwan.

Source: Interviews with Japanese umeboshi processors.

at the time were improvement of shiraboshi in quality and expansion of production in quantity. To these ends, Japanese umeboshi processors conducted the following three measures. (1) Technical guidance, specifically, how to pickle and dry ume, screening criteria and so on, have been provided to Taiwanese processors as their trade partners. (2) As cultivation guidance to ume farmers, Japanese cultivation techniques have been transferred, ranging from settled planting of seedlings, disinfection, to pruning. (3) Regarding development of new producing regions in Taiwan, managers and employees of Japanese umeboshi processors and local processors repeated negotiations with local farmers and local government officials of the regions suitable for growing ume, to request the establishment of local wholesale markets and the introduction and expansion of ume production.

\section{Period of China-shift and growth (1990s-early 2000s)}

In the late 1980s, as mentioned before, the demand for umeboshi increased greatly in Japan, due to the growth of health-conscious consumption and of the food-service industry there. Domestic production alone was not enough to keep up with the demand, so the demand for Taiwanese products surged, especially for industrial and low-priced household use. But the exportoriented food processing industry declined in Taiwan, due to increasing labor costs and a shrinking agricultural sector accompanied with economic development. Taiwanese processors then rushed to transfer their manufacturing bases to Amoy in Fujian Province and Shantou in Guangdong Province of China (Figure 3).
Meanwhile, Chinese processors, who had manufactured domestic plum sweets (hua mei and mi jian), also started to produce shiraboshi for Japan, but the Taiwanese processors were taking the initiative in shiraboshi export, since they exceeded their Chinese rivals in networks with Japanese counterparts.

Main characteristics of develop-and-import actions at the time were aggressive development of new producing regions and import of final products to Japan. Firstly for development of new producing regions in China, Japanese umeboshi processors actively conducted negotiations with farmers and local governments in Fujian and Guangdong Provinces in cooperation with Taiwanese processors who were moving into China, to expand ume production. Furthermore, there were some direct investments made by Japanese processors, who established joint ventures with local firms and set up their bases there to open up new producing regions. ${ }^{7}$

Secondly, the import of final products to Japan has grown since the 2000s. Previously, Japanese firms had imported shiraboshi, and desalted, seasoned and packed them in Japan, but they started to do all the processing in China in response to low-price consumer needs amid Japan's deflationary economy. What led to this transition is the amendments of JAS laws (Law Concerning Standardization and Proper Labeling of Agricultural and Forestry Products Law No. 175, 1950) in October, 2001. Until then, even the umeboshi that was made from Chinese-made shiraboshi but finalized in Wakayama, could be sold as "umeboshi made in Kishu (traditional name for Wakayama)." Exploiting this benefit, there was little import of Chinese-made final goods that could gain 


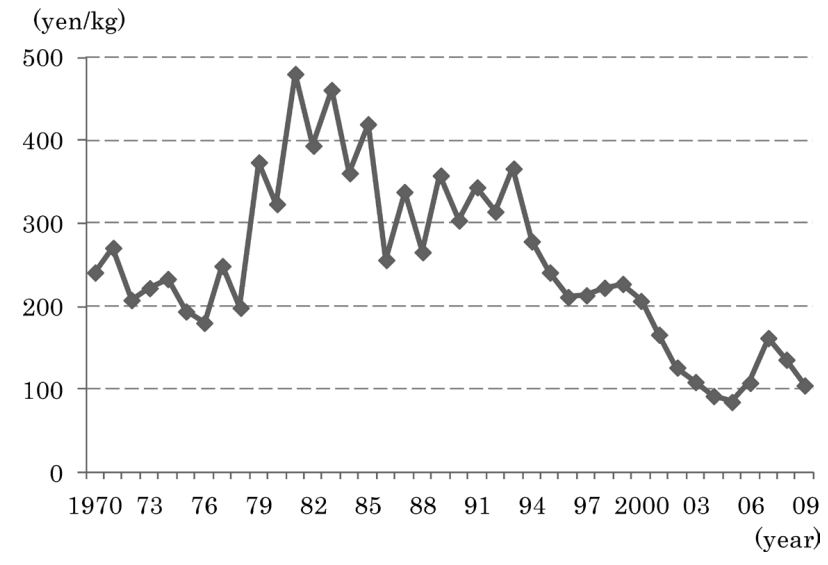

Figure 4. Trend in shiraboshi unit value in Japan. Source: Trade Statistics of Japan by Ministry of Finance.

advantage in terms of cost. To put it another way, after the mandatory labeling of origin of ingredients, either finalized in Japan or China, "made in China" must be labeled on the package, thus imports of cost-effective final products have increased.

In order to import the final products, Japanese umeboshi processors and traders provided technical and resource supports to the processors in the overseas producing regions. On the other hand, there was little direct investment by Japanese processors, unlike that mentioned above, for importing the final products. The reason lies in the changes in the supply-demand structure in Japan. Demand for umeboshi in Japan had been built on solid growth from the 1980s to the 1990s, but decreased in the 2000s due to maturation of the health food market and the prolonged recession. Amid mounting numbers of low-end consumers, demand for premium domestic umeboshi started to shrink prior to the import. Meanwhile, the amount of Chinese import increased year after year, as the demands for industrial and low-priced household uses were maintained, but Japanese umeboshi processors expected that imported umeboshi would also eventually become excess supply. Thus many processors avoided additional direct investment for importing final products, and adopted Original Equipment Manufacture (OEM) systems with the processors in the overseas producing regions.

\section{Period of diminished imports (late 2000s)}

With the recent frequent occurrence of incidents in which the safety of Chinese foods was called into question, the amount of Chinese plum imports plunged rapidly, to $60 \%$ of its peak. In the midst of declining Chinese imports, more and more Chinese and Taiwanese processors withdrew from an operation of exporting umeboshi to Japan, and more and more
Japanese processors and trading companies withdrew from operations of processing plants of themselves (subsidiaries) and develop-and-import schemes. Even the processors continuing umeboshi exports to Japan, decreased the proportion of export operation to Japan in all their businesses, and many of them strengthened sales of hua mei and mi jian for the domestic market, as well as shifting to other items. Also, many of the Japanese umeboshi processors withdrawing from processing plants of themselves (subsidiaries), switched to imports through trading firms.

Since 2009, the amount of import is recovering, but ensuring quality and safety has become an urgent issue. The issue of quality relates to ume, the chief raw material of umeboshi. The quality of the raw material is degrading because of price stagnation in recent years. As in Figure 4, the import price for shiraboshi is stagnant due to its excess supply, which leads to another slump in the farmer gate price, as low as 1.2 yuan in 2010, down from 5 yuan per $\mathrm{kg}$ in $2000 .{ }^{8}$ Consequently more and more farmers cannot afford sufficient fertilizers and pesticides; this stuation brings about quality deterioration.

The issues of safety include insufficiency of traceability. Currently, there is no mechanism for identifying a pickling tank from shiraboshi and processed products at the stage of export. A Japanese processor notes that building the system requires considerable length of time and costs, and the implementation is not practical.

\section{Dynamics of the East Asian Food Systems}

Dynamics of the East Asian food systems are examined here through the case of the develop-and-import scheme of umeboshi. As we have seen in Section Two, a growing amount of intra-regional food trade is one of structural features of the East Asian food systems recognized as "joint entity," that is, an intersection of each country's food system through food trade. In the last two decades, processed food trade, from China and the ASEAN nations to Japan, has been established as a capital trading pattern. Here, the central point is the fact that a leading actor in enlarging intra-regional trade has been Japanese agribusiness firms. So, in what follows, we approach dynamics of the East Asian food systems by analyzing the developmental mechanism in the develop-andimport schemes by umeboshi processors who belong to agribusinesses.

Umeboshi import to Japan was started in 1962 from Taiwan, and the base of export was changed to China in the 1990s. After the 1970s, Asian NIEs, including 
Taiwan and South Korea, developed greatly through industrialization. It was the food industry that played an essential role in the early phase of the economic development (Shimowatari 2008). After the 1980s, as huge economic development brought by industrialization (machinery-related and mechatronics industries) was seen in Taiwan and South Korea, the export hubs of the food industry were moved to China and Southeast Asia (Figure 3). Consequently, also for umeboshi, many Taiwanese processors moved to their manufacturing base to China for cost advantage.

Although such relocation of producing regions from Taiwan to China can be explained to some extent by economic disparities and development stages of each economy often likened to flying geese (economic distances, so to speak). However, paying an attention to behavioral logic of umeboshi processors as individual agents unfolds some parts that cannot be explained by economic distance. For example, it was Taiwanese processors that played a leading role in relocating the producing regions of ume and manufacturing base of umeboshi to China, as trade partners of Japanese processors. To find the reason, "cultural distance" (commonalities of language, religion, values and norms, as well as the degree of trust toward the other party) and "political distance" (extents of differences in political stance, bias toward domestic industries and companies, and openness of market, etc.) among Japanese, Taiwanese and Chinese processors are examined below.

According to Japanese umeboshi processors, the greatest reasons that the Japanese firms could start operations in Taiwan were that Taiwanese people were favorable to Japanese people and some of them could communicate in Japanese. Processing companies of both nations soon built relations of trust in doing business, that enabled them to maintain business, smoothly transfer technology and develop producing regions. The two aforementioned facts, presence of Taiwanese speaking Japanese and favorable attitudes toward Japan, have helped in facilitating the business. The two facts can be interpreted as the smallness of cultural distance between Taiwan and Japan (in terms of language and trust). With regard to political distance between the two, it has not been a problem in conducting economic activities, because Japanese enterprises have made direct investments in Taiwan since the 1950s even though there have not been normal diplomatic relations between Taiwan and Japan (Watanabe and Asamoto 2010). Meanwhile, also for China, political distance between China and Japan have been shrinking due to the open reform policies since 1978. Nevertheless, differences in business practices and the fact that few Chinese could communicate in Japanese hindered Japanese umeboshi processors in expanding to China in the 1990s. These points indicate a large cultural distance between Chinese and Japanese. It was difficult for small-scale Japanese umeboshi processors to build a network with Chinese counterparts in such a situation, therefore the cooperation of the Taiwanese counterparts was indispensable. There have been networks of kinship and business constructed between Taiwanese and Chinese companies out of socalled hua chiao (kakyo) and ethnic Chinese networks. This suggests a small cultural distance between Taiwanese and Chinese. Besides, even the political distance that has divided between Taiwan and China after the World War II has become no longer an obstacle in business, due to Taiwan's policy of separation of politics from economics and China's preferential policies toward Taiwan after the 1990s (Watanabe and Asamoto 2010). Accordingly, with small cultural and political distances with both China and Japan, Taiwanese processing firms have played a major role in laying out the develop-and-import schemes of umeboshi in Southern China.

Given the above analyses, understanding processes of producing region relocation from Taiwan to China from the behavioral logic of umeboshi processors reveals that a critical element has been cultural and political distances that have influenced business relations between umeboshi processors as individual agents. This point can never be seen only by an analysis of statistical data, implying the significance of focusing on deployment of agribusinesses as individual agents in order to capture the dynamics of the East Asian food systems.

Last is to raise the issue of the future of the East Asian food systems. This involves an evaluation of developand-import by Japanese processing and trading firms. Some problems have been pointed out for some time, such as inferior labor conditions and the destruction of local environment (Murai 1988; Otsuka 2005). In the case of umeboshi, while there were some rewarding aspects including creation of job opportunities resulting from agricultural promotion and development of food manufacturing industry in the region where the developand-import took place, the perspective of sustainable development seemed to be deficient there. Due to the decrease in umeboshi demand in Japan, the farmer's gate price has collapsed in the last decade, from 5 yuan (in 2000) to 1.2 yuan (in 2010). Since the break-even point of plum famers is 3.5 yuan, the lives of plum farmers are poor. We wonder if Japanese processing and trading companies, who have actively promoted development 
of producing regions, have some social responsibility concerning this situation. As the develop-and-import which makes light of local agriculture, food industry, and environmental sustainability has been argued not only with umeboshi but also with shrimps (Murai 1988) and eels (Otsuka 2005), we can point out that it is a structural problem of the East Asian food systems. Ethical behavior of agribusinesses is considered to be necessary in order to realize sustainable development of the East Asian food systems.

\section{Concluding Remarks}

This article has focused on the East Asia food systems as chains of food production, supply and consumption in the East Asia, and analyzed its structural characteristics and dynamics. The section below sets out the findings from the study.

Structural characteristics of the East Asian food systems are summarized from both aspects of "collective entity" and "joint entity" as follows. Firstly, the common structural characteristics as "collective entity" (comprehending each country's food system separately) are Westernization and sophistication of diets in the East Asian region. Not only in Japan, Taiwan and South Korea, but also in China and ASEAN nations, the intake of animal protein has been increasing in recent years. Because of this, imported amounts of feed grains and meats have notably increased.

Next, one of the structural characteristics of the "joint entity" (intra-regional food trade) is the growth of food trade in a major pattern that is composed of Japan as an importer, and China and ASEAN countries as exporters. In the last two decades, trade items have changed from raw materials to processed foods. This transition can be recognized as the increasing value-added of the food trade (McMichael 2000).

It is obvious that Japanese agribusiness firms have taken a leading role in enlarging intra-regional trade. This article has closely looked at the realities of the dynamics within the East Asian food systems by analyzing the developmental mechanism of the develop-and-import schemes by umeboshi processors. As a result, increased understanding of the processes of producing region relocation from Taiwan to China in the 1990s from the behavioral logic of umeboshi processors unveils that a key element has been cultural and political distances that affect business relations between umeboshi processors as micro-level agents, in the midst of such macro-scale movement as economic development in East Asia. This point suggests the significance of focusing on deployment of agribusinesses as individual agents in order to capture the dynamics of the East Asian food systems.

At the end of this paper, we would like to refer to the tasks ahead. One is an analysis of the East Asian food systems as a "collective entity" (comprehending each nation's food system separately). In this paper, we have analyzed commonalities in each country's food system, but the differences have hardly been touched. In order to construct stable East Asian food systems, each East Asian nation has to understand and respect each other's food system. But in Japan, little is known about the picture of each nation's food system in East Asia, except for some pioneering works such as Araki $(2008,2010)$ which clarify the supply systems of fruits and vegetables in East Asia (China and South Korea) in the field of geography. It is apparent that further accumulation of study is vital.

The other need is to accumulate case studies in a variety of commodities. Umeboshi is an isolated case in the sense that it is a traditional food peculiar to Japan, and that small-scale agribusinesses take the lead in the commodity chains. There are many other items, whose commodity chains stretch out in East Asia, such as frozen foods and tropical fruits. It can be considered that an accumulation of these case analyses would lead to a deeper understanding of the East Asian food systems.

\section{Acknowledgements}

The author would like to express sincere gratitude to Professor Yoko Niiyama (Kyoto Univ.) and Associate Professor Hideyuki Tsujimura (Kyoto Univ.) for their valuable comments and continuous guidance. The main outline of this paper was presented at the 5th JapanKorea-China Joint Conference on Geography in 2010 (Tohoku University). This study was partly supported by a Grant-in-Aid for JSPS Fellows 2010 (Representative: Takashi Norito, Proposal Number: 09J00247).

\section{Notes}

1. The food system research association of Japan has held symposiums titled "requirements for formation of the East Asian food system bloc" at its annual meetings three years in a row since 2008. Researchers from China, Korea and Japan gathered to present existing circumstances and challenges of each nation's food system (Shimowatari and Natori 2010). On the other hand, there seems little discussion on how to define the concept of the East Asian food systems.

2. For the theory of food regime, see Friedmann and McMichael (1989), Friedmann (1993), Takayanagi (2006) and Araki et al. (2007). 
3. For the commodity chains approach, see Tsujimura (2004), Araki (2007) and Araki et al. (2007). Also see Hughes and Reimer (2004) and Araki (2008) for experimental studies by the commodity chains approach in the field of geography.

4. Taiwan and South Korea made policy changes from importsubstituting to export-oriented industrialization in the 1960s, that underlay rapid economic development after the 1980s (Watanabe and Asamoto, 2010).

5. Processed foods range from low processed ones, including frozen beef and vegetables, to highly processed ones, such as fried squid and chicken nuggets.

6. According to Japanese umeboshi processors, the incident of most influence was that some Chinese-made frozen dumplings (jiao$z i$ in Chinese or gyoza in Japanese) were found to contain poison between 2007 and 2008. Just after the incident, these processors were suspended dealing with Chinese-made umeboshi by a large number of their client retailers.

7. According to the findings of interviews with Japanese umeboshi processors and the related materials, direct investments by Japanese umeboshi processors were actively made between the late 1990s and 2000s, as at least about ten of them are identified as having invested.

8. Derived from the findings of interviews with Japanese umeboshi processors.

\section{References}

Araki, H. 2007. Global commodity chain approach and geography. Japanese Journal of Human Geography 59: 151-171. (JE)

Araki, H. 2008. Fruit and Vegetable wholesale market in Asia: Advent of the national-scale supply system in South Korea, China and India. Tokyo: Association of Agriculture and Forestry Statistics. (J)

Araki, H. 2010. Agricultural production, domestic distribution and export of China: For a growing understanding of their regional diversity and our agricultural import. E-journal GEO 4: 52-68. (JE)

Araki, H., Takahashi, M., Goto, T., Ikeda, M., Iwama, N., Iga, M., Tatemi, J. and Ikeguchi, A. 2007. New theoretical trends in food geography and the perspective on Japan. E-journal GEO 2: 43-59. (JE)

Dowling, M. and Cheang, C. 2000. Shiftng comparative advantage in Asia: New tests of the "flying geese" model. Journal of Asian Economics 11: 443-463.

Friedmann, H. 1993. The political economy of food: A global crisis. New Left Review 197: 29-57.

Friedmann, H. and McMichael, P. 1989. Agriculture and the state system: The rise and decline of national agriculture, 1870 to the present. Sociologia Ruralis 29: 93-117.

Gertler, S. 1993. Implementing advanced manufacturing technologies in mature industrial regions: Towards a social model of technology production. Regional Studies 27: 665680.

Hughes, A. and Reimer, S. eds. 2004. Geographies of commodity chains. London: Routeledge.

Kanada, N. 2008. The Structure of East Asian food trade and its change: From data based on BEC classification. Journal of Rural Community Studies 107: 1-13. (JE)

Kojima, K. 2000. The "flying geese" model of Asian economic development: Origin, theoretical extensions, and regional policy implications. Journal of Asian Economics 11: 375-401.

McMichael, P. 2000. A global interpretation of the rise of the East Asian food import complex. World Development 28: 409-424.

Ministry of Agriculture, Forestry and Fisheries. 1995. Heisei 6 nen ban Zusetsu Nogyo Hakusho (Illustrated White Paper on Agriculture for the Year 1994). Tokyo: Association of Agriculture and Forestry Statistics. (J)

Mizuno, M. 1997. Interfirm linkages and proximity: A case study of Japanese automobile industries. Geographical Review of Japan 70A: 352-369. (JE)

Mizuno, M. 2001. Techological innovations, inter-firm networks and distance: A geographical analysis of patent data in the Japanese automobile industry. Japanese Journal of Human Geography 53: 18-35. (JE)

Murai, Y. 1988. Ebi to Nihon-jin (Shrimps and Japanese people). Tokyo: Iwanami-Shoten. (J)

Niiyama, Y. 2001. Gyuniku no hudo shisutemu (Beef food system). Tokyo: Nihon Keizai Hyoronsha Ltd. (J)

Norito, T. 2011. Spatial structure of umeboshi food system. Journal of Food System Research 18: 18-28. (JE)

Otsuka, S. 2005. Ajia wo mezasu hoshoku Nippon (Food-infatuated Japan aiming for Asia). Tokyo: Ie-no-hikari Association. (J)

Pankaj, G. 2007. Redefining global strategy: Crossing borders in a world where differences still matter. Boston: Harvard Business School Press.

Shimowatari, T. 2008. Higashi Ajia hudo shisutemu no shinkyokumen (New phase of the East Asian food systems). In Shokuryo jukyu to keizai hatten no shoso (Aspects of the food demand and supply and the economic development), ed. H. Uehara, T. Shimowatari and K. Itagaki, 49-62. Tokyo: Tsukuba-Shobo. (J)

Shimowatari, T. and Natori, M. 2010. Food-system linkages and value chain buildings in the East Asian countries. Journal of Food System Research 17 (2): 64-75. (JE)

Suzuki, N. 2008. Higashi Ajia chiiki no shokuryou anzen hoshou (Food security in the East Asia region). Nogyo to Keizai (Agriculture and Economy) 74(14): 39-47. (J)

Takahashi, M. and Saito, O. eds. 2002. Hudo shisutemu gaku no riron to taikei (Theory and system of food system studies). Tokyo: Association of Agriculture and Forestry Statistics. (J)

Takayanagi, N. 2006. Global transformation of spatial structure in agro-food systems. Tokyo: Tsukuba-Shobo. (J)

Toyoda, T. 2009. Regional cooperation for the food security in East Asia. Journal of Rural Economics (Special Issue 2009): 475-482. (JE)

Tsujimura, H. 2004. Kohii to namboku mondai (Coffee and northsouth problem). Tokyo: Nihon Keizai Hyoronsha Ltd. (J)

Watanabe, T. and Asamoto, T. 2010. Taiwan keizai dokuhon (Reading book on Taiwan's economy). Tokyo: Keiso Shobo. (J)

(J): written in Japanese

(JE): written in Japanese with an English abstract 